\title{
Evaluation of yield, chemical composition and yield of essential oil of four cultivars of sweet basil (Ocimum basilicum L.) affected by different levels of nitrogen
}

\author{
Faraj MOAYEDI ${ }^{1,2}$, Sajad KORDI ${ }^{3}$, Ali Ashraf MEHRABI ${ }^{4}$
}

Received February 21, 2019; accepted February 8, 2020. Delo je prispelo 21. februarja 2019, sprejeto 8. februarja 2020.

Evaluation of yield, chemical composition and yield of essential oil of four cultivars of sweet basil (Ocimum basilicum L.) affected by different levels of nitrogen

Izvleček: A field experiment was conducted to evaluate yield and some qualitative characteristics of four cultivars of sweet basil treated with different levels of nitrogen fertilizer. The experiments were located on the Agricultural Research Station of Khorramabad, Iran, during the 2016-2017 growing season. Treatments were arranged in factorial split-plot-in time in randomized complete block design with three replications. Experimental treatments were four cultivars of sweet basil (Ocimum basilicum 'Italian Large Leaf', O. basilicum 'Mobarakeh', O. basilicum 'Cinnamon' and O. basilicum 'Thai'), three levels of nitrogen fertilizer $\left(0,100\right.$ and $200 \mathrm{~kg} \mathrm{ha}^{-1}$ urea) and three harvests. The highest total dry mass $\left(3482.4 \mathrm{~kg} \mathrm{ha}^{-1}\right)$ was related to 'Italian Large Leaf' with the application of $200 \mathrm{~kg} \mathrm{ha}^{-1}$ urea at the second harvest. The maximum $\left(26.79 \mathrm{~kg} \mathrm{ha}^{-1}\right)$ essential oil yield belonged to $100 \mathrm{~kg} \mathrm{ha}^{-1}$ urea. The highest concentrations of main constituents of essential oil, except methyl chavicol, 1,8-cineole and methyl cinnamate were obtained by control (without nitrogen fertilizer). Italian Large Leaf cultivar and application of $100 \mathrm{~kg} \mathrm{ha}^{-1}$ urea are recommended to access an acceptable agricultural yield and essential oil yield in sweet basil under the environmental condition similar to Khorramabad.

Key words: basil; dry mass; essential oil; main constituents of essential oil; urea
Ovrednotenje pridelka, kemijske sestave in pridelka eteričnih olj štirih sort navadne bazilike (Ocimum basilicum L.) pri različnem gnojenju $\mathrm{z}$ dušikom

Abstract: Za ovrednotenje pridelka in nekaterih kakovostnih lastnosti štirih sort navadne bazilike je bil izveden poljski poskus z različnimi odmerki dušikovih gnojil. Poskus je potekal na Agricultural Research Station of Khorramabad, Iran, v rastni sezoni 2016-2017. Obravnavanja so bila izvedena v naključnem faktorskem bločnem poskusu $\mathrm{z}$ deljenkami s tremi ponovitvami. Obravnavane so bile štiri sorte navadne bazilike (Ocimum basilicum 'Italian Large Leaf', O. basilicum 'Mobarakeh', O. basilicum 'Cinnamon' and O. basilicum 'Thai'), tri ravni gnojenja $\mathrm{z}$ dušikovimi gnojili $\left(0,100\right.$ in $200 \mathrm{~kg} \mathrm{ha}^{-1}$ uree) in tri žetve. Največjo celukupno suho maso $\left(3482,4 \mathrm{~kg} \mathrm{ha}^{-1}\right)$ je imela sorta Italian Large Leaf pri uporabi $200 \mathrm{~kg} \mathrm{ha}^{-1}$ uree $\mathrm{v}$ drugi žetvi. Največji pridelek eteričnih olj $\left(26,79 \mathrm{~kg} \mathrm{ha}^{-1}\right)$ je bil dosežen pri $100 \mathrm{~kg} \mathrm{ha}^{-1}$ uree. Največja vsebnost glavnih komponent eteričnih olj, razen metil kavikola, 1,8-cineola in metil cinamata, je bila pri kontroli (brez gnojenja $\mathrm{z}$ dušikovimi gnojili). Sorta Italian Large Leaf in uporaba $100 \mathrm{~kg} \mathrm{ha}^{-1}$ uree sta priporočeni za doseganje sprejemljivega agronomskega pridelka in pridelka eteričnih olj navadne bazilike $\mathrm{v}$ okoljskih razmerah podobnih tistim v Khorramabadu.

Ključne besede: navadna bazilika; suha masa; eterično olje; glavne sestavine eteričnega olja; urea

Islamic Azad University, Khorram-Abad Branch, Faculty of Agriculture, Department of agronomy

2 Corresponding author, e-mail: faraj.moayedi1362@gmail.com

3 Islamic Azad University, Young Researchers and Elite Club, Khorram-Abad Branch, Khorram-Abad, Iran

4 University of Ilam, Faculty of Agriculture,Department of agronomy and plant breeding, Iran 


\section{INTRODUCTION}

Sweet basil (Ocimum basilicum L.) is one of the oldest spices belonging to the Labiatae family, an herbaceous annual plant, native to Asia, Africa, America and the Subtropics (Roman, 2012; Borloveanu, 2014). The basil is rich in secondary metabolites and essential oil of therapeutic importance. Therefore, it has been used in traditional medicine as a tonic, diuretic, analgesic, anti-inflammatory, anticancer and also to prevent cardiovascular disease complications (Krishnaiah et al., 2009; Srivastava et al., 2014; Li et al., 2017). Basil is an important economic crop and widely used in the culinary arts, food processing and pharmaceutical industries (AlMaskri et al., 2011; Beatović et al., 2015). There are many cultivars of sweet basil which vary in their leaf colors (green or purple), flower color (white, red, purple) and aroma. Sweet basil has been classified into seven different morphotypes, which include 1 ) tall, slender types; 2 ) large-leafed types ('Italian' basils); 3) dwarf types ('Bush' basils); 4) compact types ('Thai' basils); 5) purple types (with clove-like aroma); 6) 'Purpurascens' types (sweet purple colored basils); and 'Citriodorum' types (flavored basils) (Simon et al., 1999). The chemical composition of sweet basil essential oil depends on genetic, season, environmental factors and the plant growth stage (Bilal et al., 2012). Padalia et al. (2014) has reported linalool, methyl chavicol, methyl eugenol, eugenol and geraniol as dominant components in the basil essential oil.

Nitrogen is one of the most important nutrients for plant production that plays a major role in photosynthetic activity and crop yield capacity and its availability influence plants growth and biochemical parameters (Werner \& Newton, 2005; Caliskan et al., 2008). The promoting effect of nitrogen on growth parameters can be explained on the basis of the fact that nitrogen is involved in all parameters of growth through structure and regulation, among them supply increases the number and size of meristematic cells which leads to the formation of new shoots and leaf expansion (Lawlor, 2002).

Growth and yield of basil, like in other cultivated plants, depend upon the availability of all nutrients in the nutritional environment; besides, the yield quality is closely connected with macro- and micro-elements taken up. It is reported that nitrogen application significantly increase the herb yield of basil grown in different climatic conditions (Zheljazkov et al., 2008). According to Zheljazkov et al. (2008), the relationship between nitrogen levels and basil plants growth was characterized by quadratic polynomial model, the highest values being reached at approximately $60 \mathrm{~kg} \mathrm{ha}^{-1} \mathrm{~N}$. However, Sifola \& Barbieri (2006) reported that the highest fresh mass of basil occurred in $300 \mathrm{~kg} \mathrm{ha}^{-1}$ of nitrogen ferti- lization. The conditions such as climatic and nutrient factors suitable for plant growth are of the most important factors affecting the growth of medicinal plants and qualitative and quantitative characteristics of essential oil (Street, 2012). Reporting research findings showed that nitrogen markedly changed the amount of linalool, eugenol, methyl chavicol, Z-citral (neral), geranial, (E)caryophyllene, trans- $\alpha$-bergamotene, $\alpha$-humulene and eucalyptol of essential oil of sweet basil (Zheljazkov et al., 2008; Nurzyńska-Wierdak et al., 2013; Kordi, 2017). In a field research with mint (Mentha arvensis L.), the effect of three levels of nitrogen fertilizer $\left(0,100\right.$ and $200 \mathrm{~kg} \mathrm{ha}^{-1}$ nitrogen) on essential oil yield was investigated. The results showed that the highest amount of essential oil in mint was obtained from application of $100 \mathrm{~kg} \mathrm{ha}^{-1}$ nitrogen (Ram et al., 1998).

Excessive nitrogen fertilizer may negatively affect the uptake of other nutrients, and also its high water-solubility of nitrogen leads to increased runoff into surface water as well as leaching into groundwater, thereby causing groundwater pollution. So, determining an appropriate dose of $\mathrm{N}$ fertilizer in line with feeding crops results in not only higher yield quantitatively and qualitatively, but also less damage to agricultural system and environment. Moreover, the yield and qualitative characteristics of the cultivars, investigated fully throughout this experiment, have not been studied under a certain climate in the previous researches, so far. The aim of the present research was to determine the effect of the rate of nitrogen fertilizers on agricultural yield, essential oil content and composition in four basil cultivars: 'Italian Large Leaf', 'Mobarakeh', 'Cinnamon' and 'Thai'.

\section{MATERIALS AND METHODS}

\subsection{LOCATION AND PLANT MATERIALS}

This field experiment was conducted in the Agricultural Research Station of Khorramabad, Iran $\left(33^{\circ} 27^{\prime} \mathrm{N}\right.$, $48^{\circ} 17^{\prime} \mathrm{E}$, and altitude 1,162 m), during 2016 - 2017 growing season. Physical soil analysis and chemical characteristics of soil at the depth 0-30 cm are shown in Table 1.

Before cultivation, $100 \mathrm{~kg}$ triple superphosphate $\mathrm{ha}^{-1}$ and $30 \mathrm{~kg}$ potassium sulfate ha ${ }^{-1}$ were added to plots according to soil test. Nitrogen (as urea; $46 \% \mathrm{~N}$ ) in two phases was distributed: half of the amount of nitrogen was added to plots with the last tilling before planting and the rest of the nitrogen after the first harvest. Seeds of sweet basil were planted by hand in plots, whose area was $5 \mathrm{~m}^{2}$, consisting of five 2-meter rows spaced $50 \mathrm{~cm}$ apart and $2.5 \mathrm{~cm}$ intra-row plant spacing on May $25^{\text {th }} 2016$. All plots were irrigated immediately after sowing. Sub- 
Table 1: Physical and chemical analysis of soil before the experiment

\begin{tabular}{llllllllll}
\hline Soil texture & $\begin{array}{l}\text { Clay } \\
(\%)\end{array}$ & $\begin{array}{l}\text { Silt } \\
(\%)\end{array}$ & $\begin{array}{l}\text { Sand } \\
(\%)\end{array}$ & $\mathrm{pH}$ & $\begin{array}{l}\mathrm{EC} \\
\left.(\mathrm{dS} \mathrm{m})^{-1}\right)\end{array}$ & $\begin{array}{l}\mathrm{OC} \\
(\%)\end{array}$ & $\begin{array}{l}\text { Total N } \\
(\%)\end{array}$ & $\begin{array}{l}\text { Available P Available K } \\
(\mathrm{ppm})\end{array}$ & $\begin{array}{l}\text { (ppm) } \\
(\mathrm{p})\end{array}$ \\
\hline Silty clay loam & 39 & 48 & 13 & 7.7 & 0.5 & 1.04 & 0.22 & 7 & 335 \\
\hline
\end{tabular}

sequent irrigations were carried out every 4 days. Hand weeding of the experimental area was performed when required.

\subsection{EXPERIMENTAL DESIGN AND TREATMENTS}

This experimental design was a factorial split-plotin time experiment based on Randomized Complete Block Design (RBCD) with three replications. Experimental treatments were four cultivars of sweet basil $(O$. basilicum 'Italian Large Leaf', O. basilicum 'Cinnamon', O. basilicum 'Thai' and O. basilicum 'Mobarakeh' (native basil cultivar has been cultivated in many regions of Iran), three levels of nitrogen fertilizer included; N1: control (without urea fertilizer); N2: $100 \mathrm{~kg} \mathrm{ha}^{-1}$ urea; N3: $200 \mathrm{~kg} \mathrm{ha}^{-1}$ urea, and three harvests. Mobarakeh cultivar was provided from Pakan-Bazr institute, Isfahan and three foreign cultivars of basil were obtained from Eden Brothers Company in the United States.

\subsection{TRAITS MEASUREMENT}

The traits measured in this study included leaf dry mass, total dry mass, essential oil percentage, chemical composition and yield of essential oil sweet basil.

\subsection{MEASURING LEAF DRY MASS AND TOTAL DRY MASS}

The sweet basil was harvested three times each season in early flowering stage on the July $12^{\text {th }}$, August $15^{\text {th }}$, and September $25^{\text {th }}$. Samples along $1 \mathrm{~m}$ of length were taken from the center of two rows, located in the middle of each plot. Plants above ground was cut and transferred into a lab to measure leaf and total mass. To measure dry mass, the samples were dried in an oven at $75^{\circ} \mathrm{C}$ for $72 \mathrm{~h}$ and then weighed. For essential oil extraction the aerial parts of sweet basil plants were dried naturally in the shade.

\subsection{MEASURING ESSENTIAL OIL CONTENT}

Fifty grams of dried aerial parts (both stems and leaves) were sampled for analysis. Woody parts were separated and the remainder hydro-distilled for $4 \mathrm{~h}$, using a Clevenger-type apparatus (Anonymous, 1996). The distilled essential oils were dried over anhydrous sodium sulfate, filtered and stored in sealed vials at $4{ }^{\circ} \mathrm{C}$, prior to further analyses. To measure main constituents of essential oil, all treatments belonged to a given repetition were chosen in second harvest.

\subsection{GAS CHROMATOGRAPHY-MASS SPECTROM- ETRY (GC-MS)}

The oil samples were analyzed in a gas chromatography Agilent model 7890 using HP-5MS column $(30 \mathrm{~m}$ $\times 0.25 \mathrm{~mm}, 0.25 \mathrm{~mm}$ in thickness). The oven temperature was programmed from $50{ }^{\circ} \mathrm{C}$ (held for $2 \mathrm{~min}$ ) and increased to $240{ }^{\circ} \mathrm{C}$ at a rate of $3{ }^{\circ} \mathrm{C} \mathrm{min}$ men $^{-1}$ the $240{ }^{\circ} \mathrm{C}$ to $300^{\circ} \mathrm{C}$ at a rate of $15^{\circ} \mathrm{C} \mathrm{min}^{-1}$. Helium was used as carrier gas with a constant flow rate of $1 \mathrm{ml} \mathrm{min}^{-1}$. The mass spectra were recorded on electron ionization (EI) mode, with ionization energy of $70 \mathrm{eV}$. Temperature at the injection site was $290^{\circ} \mathrm{C}$. The identification of constituents was carried out based on the retention indices (calculated using from C8 to C20 alkanes) and by comparing the mass spectra with a computer databank (Wiley 7 and Nist 62) and with reference to published data (Adams, 2007; Carneiro et al., 2017).

\subsection{DATA ANALYSIS}

SAS (version 9.1) and MSTAT-C programs were used to conduct an analysis of variance (ANOVA) and means comparison, respectively. Treatment mean differences were separated by Duncan test at the $5 \%$ level of probability. The graphs were drawn by Excel and error bars were assigned on the basis of standard deviation (SD).

\section{RESULTS AND DISCUSSION}

\subsection{LEAF DRY MASS AND TOTAL DRY MASS}

The analysis of variance showed that cultivar had a significant effect on leaf dry mass and total dry mass. 
F. MOAYEDI et al.

Table 2: The variance analysis of agricultural yield and some qualitative properties of sweet basil cultivars

\begin{tabular}{|c|c|c|c|c|c|}
\hline Sources of variation & $\mathrm{df}$ & Leaf dry mass & Total dry mass & Percentage of essential oil & Essential oil yield \\
\hline Replication (R) & 2 & 4372.81 & 61975.13 & 0.008 & 13.99 \\
\hline Cultivar (A) & 3 & $100263.97^{* *}$ & $865900.19^{* *}$ & $2.63^{* *}$ & $2701.25^{* *}$ \\
\hline Fertilizer (B) & 2 & $1993129.8^{* *}$ & $5107691.31^{* *}$ & $0.35^{* *}$ & $246.26^{* *}$ \\
\hline$A \times B$ & 6 & $17972.91^{\mathrm{ns}}$ & $83695.26^{* *}$ & $0.007^{\mathrm{ns}}$ & $7.36^{\mathrm{ns}}$ \\
\hline Error $1(\mathrm{~A} \times \mathrm{B} \times \mathrm{R})$ & 22 & 15800.19 & 20256.08 & 0.006 & 8.24 \\
\hline Harvest (C) & 2 & $3728940.4^{* *}$ & $15436181.5^{* *}$ & $0.37^{* *}$ & $3046.94^{* *}$ \\
\hline Error $2(\mathrm{C} \times \mathrm{R})$ & 4 & 2722.3 & 17939.5 & 0.05 & 21.95 \\
\hline $\mathrm{A} \times \mathrm{C}$ & 6 & $8325.49^{\text {ns }}$ & $58284.72^{* *}$ & $0.05^{* *}$ & $207.93^{* *}$ \\
\hline $\mathrm{B} \times \mathrm{C}$ & 4 & $164325.9^{* *}$ & $187653.87^{\star *}$ & $0.003^{\mathrm{ns}}$ & $8.72^{\mathrm{ns}}$ \\
\hline $\mathrm{A} \times \mathrm{B} \times \mathrm{C}$ & 12 & $2546.9^{\mathrm{ns}}$ & $35986.78^{* *}$ & $0.004^{\mathrm{ns}}$ & $7.82^{\mathrm{ns}}$ \\
\hline Error 3 & 48 & 5140.8 & 6871.59 & 0.01 & 8.26 \\
\hline C.V (\%) & - & 6.07 & 3.37 & 10.78 & 11.97 \\
\hline
\end{tabular}

${ }^{*},{ }^{*}$ and ns show significant difference at probability of $5 \%, 1 \%$ and no significant difference, respectively

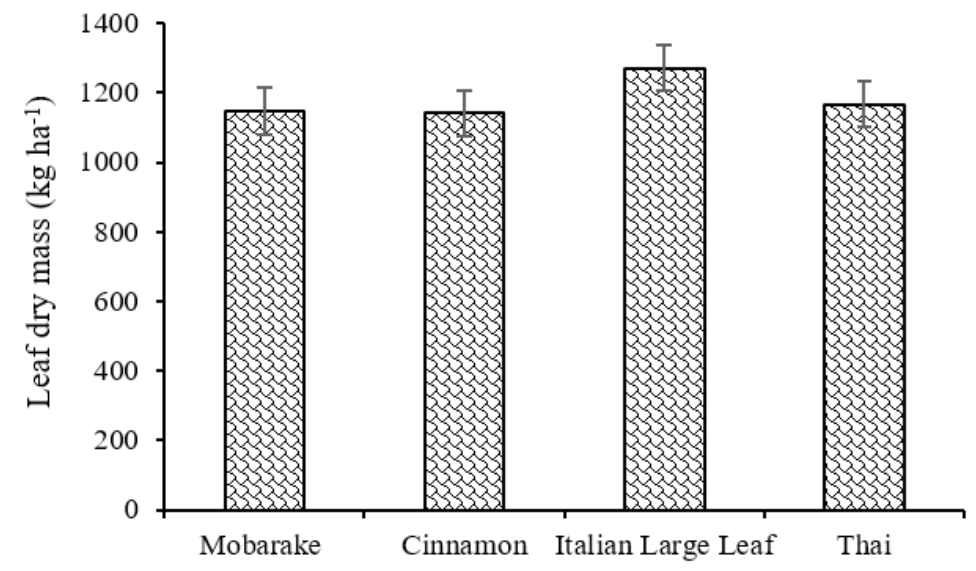

Figure 1: Leaf dry mass in different cultivars of basil

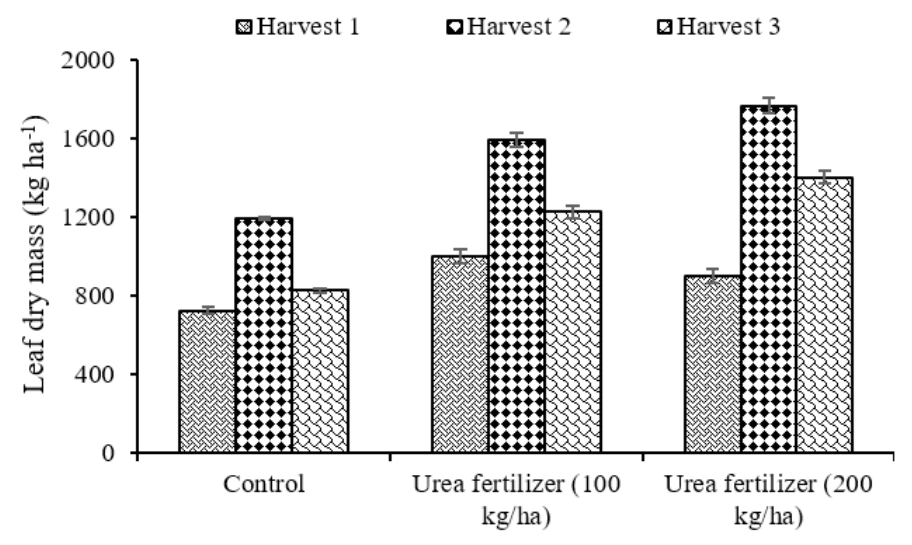

Figure 2: Leaf dry mass response of basil to different harvests under various levels of nitrogen fertilizer 
Also, simple effects of fertilization and harvest were significant on leaf dry mass and total dry mass in this study. Cultivar $\times$ harvest interaction effect was significant for the total dry mass. Also, the leaf dry mass and total dry mass were influenced by fertilizer $\times$ harvest. The interaction effects of cultivar $\times$ fertilizer and cultivar $\times$ fertilizer $\times$ harvest were only significant for total dry mass (Table 2).

Application of nitrogen fertilizer significantly improved yield in all four cultivars. Nitrogen fertilizers provide during the growing season provides a favorable environment for the production of basil, by providing the nitrogen needed for the basil plant growth and biomass production.

The highest leaf dry mass $\left(1271.3 \mathrm{~kg} \mathrm{ha}^{-1}\right)$ was related to Italian Large Leaf cultivar, but there was no significant difference among other studied sweet basil cultivars (Fig. 1). In all harvests, plants fed with urea had greater leaf dry mass compared to untreated plants. Plants in the second harvest had higher leaf dry mass compared to the first and the third harvests. The maximum leaf dry mass $\left(1766.5 \mathrm{~kg} \mathrm{ha}^{-1}\right)$ was recorded with the application of $200 \mathrm{~kg} \mathrm{ha}^{-1}$ urea at the second harvest. Untreated plants had the lowest leaf dry mass in all harvests (Fig. 2). Kandil et al. (2009) reported that nitrogen fertilization significantly increases basil leaf mass, which can be due to an increase in leaf thickness, and not only its size. Also, Kordi (2017) reported that among different sources of nitrogen fertilizers, the highest fresh and dry mass of basil leaves were recorded for plants fed with urea fertilizer in the second harvest.

The comparison of the mean values of the total dry mass (Fig. 3) showed that total dry mass of the all studied basil cultivars increased with application of nitrogen fertilizer in all harvests. Similar to leaf dry mass (Fig. 2), plants in the second harvest had the highest total dry mass compared to the first and the third harvests. The highest total dry mass $\left(3482.4 \mathrm{~kg} \mathrm{ha}^{-1}\right)$ was related to Italian Large Leaf cultivar with the application of $200 \mathrm{~kg} \mathrm{ha}^{-1}$ urea at the second harvest, although in terms of this trait had no significant difference with Italian Large Leaf cultivar with the application of 100 $\mathrm{kg} \mathrm{ha}^{-1}$ urea at the second harvest (Fig. 3). The increment in total dry mass of basil by application of nitrogen fertilizer (Fig. 3) can be attributed to increment in chlorophyll content (unpublished data) and better growth of plants and subsequently the better canopy development which ultimately leads to the better use of solar irradiance, higher photosynthesis and finally higher dry mass in basil plants. Nitrogen has an important role in the improvement of vegetative growth, resulting in increased yield. Sifola \& Barbieri (2006) reported that applying nitrogen doses (ranging between 0 to $300 \mathrm{~kg} \mathrm{ha}^{-1}$ ) resulted in a dry mass rise of the above-ground part. In other research, the highest basil herb yield $\left(23.2 \mathrm{tha}^{-1}\right)$ was obtained by application of $120 \mathrm{~kg} \mathrm{ha}^{-1} \mathrm{~N}$ (Yassen et al., 2003). Also, Biesiada \& Kus (2010) reported that nitrogen amount affects basil herb yield so that the highest yields were recorded at the dosage of $150-250 \mathrm{~kg} \mathrm{ha}^{-1} \mathrm{~N}$.

Although all plants were harvested at identical growth stage, a reduction in total dry mass of the first harvest (Fig. 3) is attributed to the effects of higher temperature of June and consequently stimulating premature flowering in spite of lower vegetative growth. In this respect, lateral branch and height of plants relative to other harvests were reduced.

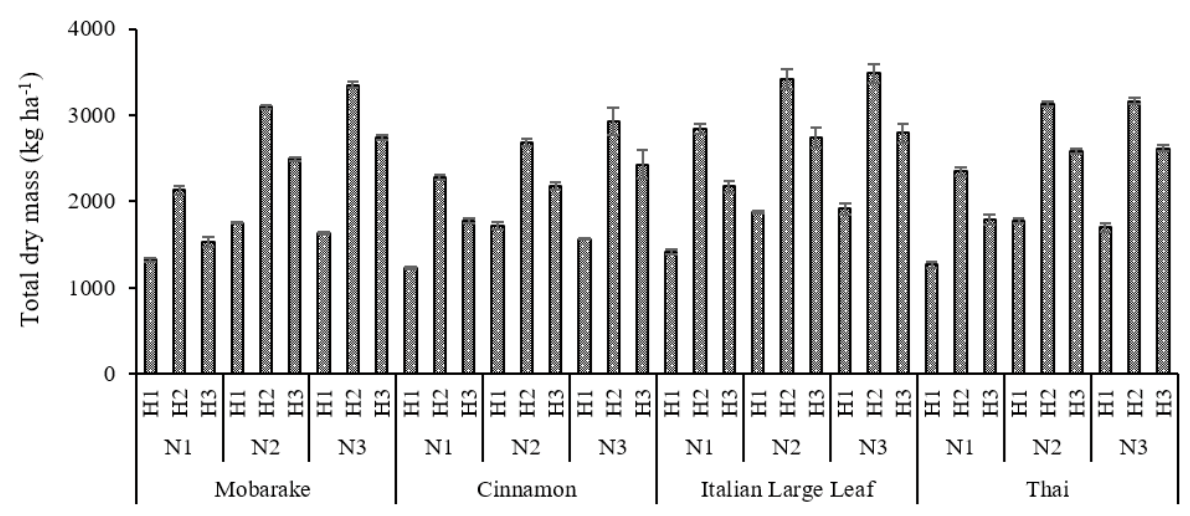

Figure 3: Total dry mass response of basil cultivars to different harvests under various levels of nitrogen fertilizer N1: (control), N2: $100 \mathrm{~kg}$ ha-1 urea, N3: $200 \mathrm{~kg}$ ha-1 urea;

$\mathrm{H} 1, \mathrm{H} 2$ and $\mathrm{H} 3$ : first harvest, second harvest and third harvest, respectively 


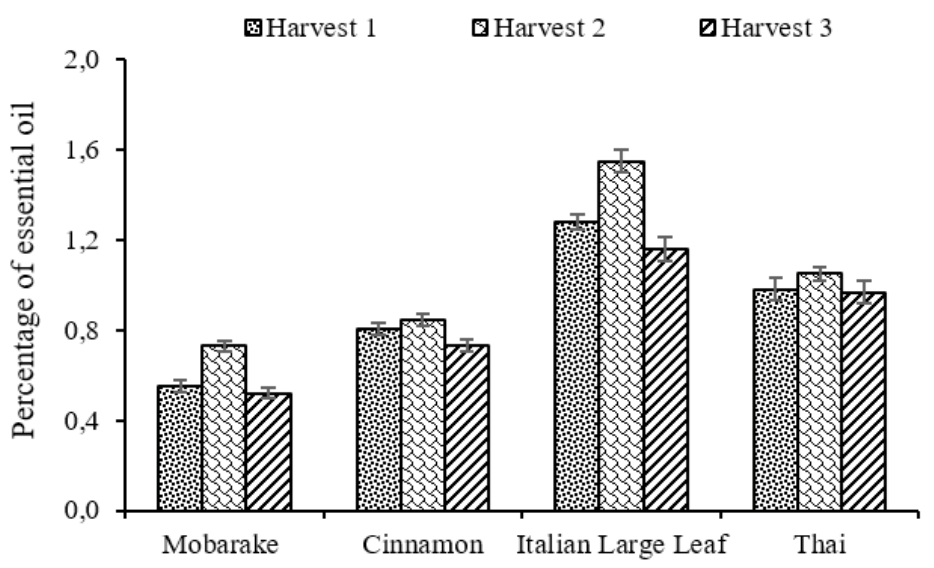

Figure 4: Percentage of essential oil response of basil cultivars to different harvests

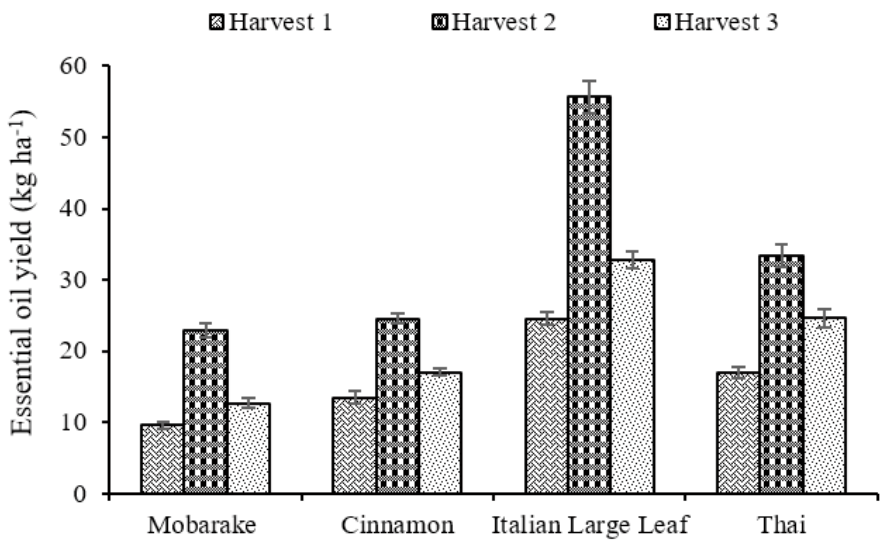

Figure 5: Essential oil yield response of basil cultivars to different harvests

\subsection{PERCENTAGE OF ESSENTIAL OIL AND ES- SENTIAL OIL YIELD}

The results of variance analysis showed a significant influence of cultivar, fertilization and harvest on the percentage of essential oil and essential oil yield $\left(\mathrm{kg} \mathrm{ha}^{-1}\right)$ (Table 2). Also, cultivar $\times$ harvest interaction effects were significant for both traits (Table 2). The comparison of the mean values showed that the highest percentage of essential oil (1.55\%) and essential oil yield (55.64 $\left.\mathrm{kg} \mathrm{ha}^{-1}\right)$ were related to Italian Large Leaf cultivar at the second harvest (Figs 4 and 5). Although all harvests were performed at the same developmental stage, plants of second harvest generated more secondary metabolites (Fig. 4) due to exposition to abundant light and carrying out more photosynthesis activities. Among three harvests of sweet basil, Jahan et al. (2012) demonstrated that the highest and lowest percentage of essential oil and essential oil yield were found in the second and the first harvests, respectively.
The results of mean comparisons showed that the highest (1.01\%) and the lowest (0.82 \%) essential oil content was related to control and $200 \mathrm{~kg} \mathrm{ha}^{-1}$ urea, respectively, but the maximum $\left(26.79 \mathrm{~kg} \mathrm{ha}^{-1}\right)$ and minimum (21.58 $\mathrm{kg} \mathrm{ha}^{-1}$ ) essential oil yield belonged to $100 \mathrm{~kg} \mathrm{ha}^{-1}$ urea and control (Figs 6 and 7). According to the results of this research, it seems that there is an inverse relationship between essential oil percentage of sweet basil and using nitrogen chemical fertilizer (Fig. 6). The superiority of controls over other treatments with high agricultural yield is attributed to an increase in secondary metabolites under environmental stress and nutritional deficiency conditions. Nitrogen fertilizer application adequately paved the way for plants to grow adequately through supplying nutritional resources. Tahami Zarandi et al. (2010) revealed that higher essential oil percentage of sweet basil was produced by not using fertilizer than with chemical fertilizer. Control (without nitrogen fertilizer) treatment gave higher essential oil percentage compared to the ni- 


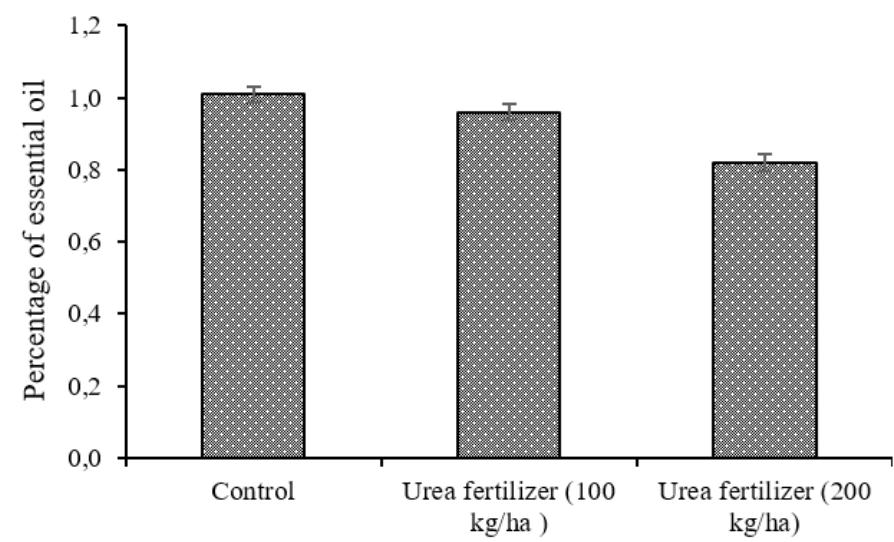

Figure 6: Percentage of essential oil response of basil to different levels of nitrogen fertilizer

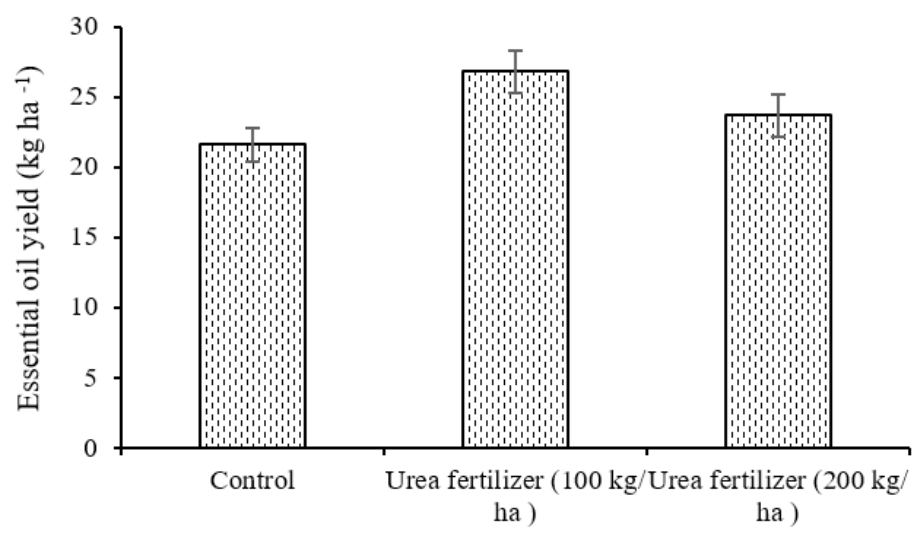

Figure 7: Essential oil yield response of basil to different levels of nitrogen fertilizer

trogen chemical fertilizers (Fig. 6). This reflected the facts that essential oil yield of sweet basil was highly affected by agricultural yield and less by essential oil percentage (Fig. 7). This experiment confirmed the hypothesis that application of nitrogen chemical fertilizer could increase essential oil yield of sweet basil, mainly due to increase in agricultural yield. Biesiada \& Kus (2010) documented that highest yield of sweet basil's aerial organs was obtained by applying $150 \mathrm{~kg} \mathrm{ha}^{-1} \mathrm{~N}$. Added nitrogen supply increases photosynthesis rate and enables the plant to grow rapidly and produced considerable biomass and basic metabolism, which may increase production and accumulation of secondary metabolites, such as essential oil (Sifola \& Barbieri, 2006).

\subsection{THE MAIN COMPONENTS OF ESSENTIAL OIL}

In addition to quantity, the quality (in terms of type and amount of constituents) of essential oil is also received great attentions while cultivation medicinal plants. The analysis of essential oil carried out on aerial parts of basil cultivars under different treatments revealed the presence of 29-35 constituents, shown in Table 3. In current research, the results revealed that the types of essential oil components could remarkably vary depending on the cultivar and the rate of applied nitrogen. Eight constituents including methyl chavicol (38.2-48.9\%), Z-citral (neral) (13.1-17.0 \%), geranial (17.3-23.0\%), (E)-caryophyllene (4.50-4.90\%), trans-a-bergamotene (1.27-1.80\%), a-humulene (1.67-1.90\%), germacrene$\mathrm{D}(0.82-1.50 \%)$, and $\gamma$-cadinene (3.00-3.20\%) were the main constituents of essential oil in the cultivar Mobarakeh (Table 3). 1,8-cineole (4.70-5.20\%), linalool (34.5-36.1\%), methyl chavicol (5.80-7.20\%), eugenol (1.50-1.81\%), methyl cinnamate (38.8-41.0\%) and germacrene-D (1.80-2.30\%) were the dominant compounds in the essential oil of cultivar Cinnamon (Table 3 ). In the 
Table 3: Essential oil constituents in sweet basil cultivars under different levels of nitrogen fertilizer (based on percentage)

\begin{tabular}{|c|c|c|c|c|c|c|c|c|c|c|c|c|}
\hline \multirow[b]{2}{*}{ Compound } & \multicolumn{3}{|c|}{ 'Mobarakeh' } & \multicolumn{3}{|c|}{ 'Cinnamon’ } & \multicolumn{3}{|c|}{ 'Italian Large Leaf' } & \multicolumn{3}{|c|}{ 'Thai' } \\
\hline & N1 & $\mathrm{N} 2$ & N3 & N1 & $\mathrm{N} 2$ & N3 & N1 & $\mathrm{N} 2$ & N3 & N1 & $\mathrm{N} 2$ & $\mathrm{~N} 3$ \\
\hline a-Pinene & 0.20 & 0.21 & 0.21 & 0.28 & 0.25 & 0.32 & 0.26 & 0.30 & 0.31 & 0.16 & 0.20 & 0.22 \\
\hline Camphene & 0.69 & 0.60 & 0.63 & $\operatorname{tr}$ & $\operatorname{tr}$ & $\operatorname{tr}$ & 0.11 & $\operatorname{tr}$ & $\operatorname{tr}$ & $\operatorname{tr}$ & $\operatorname{tr}$ & $\operatorname{tr}$ \\
\hline$\beta$-Pinene & 0.36 & 0.37 & 0.30 & 0.45 & 0.50 & 0.40 & 0.67 & 0.60 & 0.61 & 0.29 & 0.33 & 0.30 \\
\hline Myrcene & 0.15 & 0.15 & 0.10 & 0.29 & 0.26 & 0.30 & 0.49 & 0.53 & 0.5 & 0.40 & 0.45 & 0.32 \\
\hline Limonene & 0.12 & 0.13 & 0.14 & 0.10 & 0.10 & 0.12 & 0.30 & 0.35 & 0.30 & 0.21 & 0.20 & 0.18 \\
\hline 1,8-Cineole & 0.31 & 0.40 & 0.35 & 4.70 & 5.20 & 4.70 & 8.14 & 8.30 & 8.40 & 1.45 & 1.60 & 1.50 \\
\hline (E)- $\beta$-Ocimene & 0.13 & 0.20 & 0.26 & 0.60 & 0.65 & 0.60 & 0.32 & 0.30 & 0.35 & 1.14 & 1.20 & 1.20 \\
\hline Terpinolene & - & - & - & 0.17 & 0.15 & 0.10 & 0.25 & 0.20 & 0.23 & 0.16 & 0.20 & 0.20 \\
\hline Fenchone & 0.10 & 0.15 & 0.20 & 0.22 & 0.30 & 0.30 & 0.30 & 0.30 & 0.35 & 0.24 & 0.20 & 0.30 \\
\hline Linalool & 0.20 & 0.30 & 0.25 & 34.5 & 36.1 & 34.6 & 42.4 & 44.8 & 41.9 & 40.0 & 40.1 & 39.0 \\
\hline Camphor & $\operatorname{tr}$ & $\operatorname{tr}$ & $\operatorname{tr}$ & 0.70 & 0.40 & 0.30 & 0.53 & $\operatorname{tr}$ & 0.30 & 0.75 & 0.50 & 0.50 \\
\hline Borneol & 0.32 & 0.20 & 0.25 & 0.15 & $\operatorname{tr}$ & $\operatorname{tr}$ & 0.42 & 0.30 & 0.30 & 0.40 & 0.40 & 0.20 \\
\hline Terpinen-4-ol & - & - & - & 0.73 & 0.80 & 0.95 & - & - & - & 0.21 & 0.40 & 0.40 \\
\hline$\alpha$-Terpineol & 0.26 & 0.30 & 0.20 & 0.33 & 0.35 & 0.30 & 0.71 & 0.60 & 0.55 & 1.10 & 0.90 & 0.80 \\
\hline Methyl chavicol & 38.2 & 45.2 & 48.9 & 5.80 & 6.00 & 7.20 & 30.7 & 33.2 & 37.0 & 9.30 & 10.1 & 11.3 \\
\hline Z-Geraniol (Nerol) & 0.21 & 0.40 & 0.68 & - & - & - & - & - & - & - & - & - \\
\hline Z-Citral (Neral) & 17.0 & 14.2 & 13.1 & - & - & - & - & - & - & - & - & - \\
\hline Chavicol & 0.30 & 0.20 & 0.20 & 0.40 & 0.40 & 0.50 & 0.80 & 0.75 & 0.90 & - & - & - \\
\hline Geraniol & 0.85 & 0.50 & 0.23 & - & - & - & 0.10 & $\operatorname{tr}$ & $\operatorname{tr}$ & - & - & - \\
\hline Geranial & 23.0 & 21.4 & 17.3 & - & - & - & - & - & - & - & - & - \\
\hline Bornyl acetate & 0.30 & 0.30 & 0.20 & 0.26 & 0.20 & 0.20 & 0.60 & 0.70 & 0.50 & 0.42 & 0.50 & 0.40 \\
\hline a-Cubebene & 0.20 & 0.18 & 0.15 & 0.15 & 0.20 & 0.15 & 0.40 & 0.30 & 0.30 & - & - & - \\
\hline Eugenol & 0.19 & 0.15 & 0.10 & 1.81 & 1.60 & 1.50 & 1.20 & 1.10 & 0.90 & 3.21 & 3.00 & 2.80 \\
\hline a-Copaene & 0.16 & 0.21 & 0.17 & 0.14 & 0.10 & 0.10 & $\operatorname{tr}$ & $\operatorname{tr}$ & $\operatorname{tr}$ & - & - & - \\
\hline$\beta$-Cubebene & 0.50 & 0.45 & 0.40 & - & - & - & 0.13 & $\operatorname{tr}$ & $\operatorname{tr}$ & 0.75 & 0.60 & 0.60 \\
\hline$\beta$-Elemene & 0.14 & $\operatorname{tr}$ & $\operatorname{tr}$ & 0.68 & 0.50 & 0.60 & 0.15 & $\operatorname{tr}$ & $\operatorname{tr}$ & 1.03 & 0.90 & 0.90 \\
\hline Methyl cinnamate & $\operatorname{tr}$ & $\operatorname{tr}$ & 0.10 & 38.8 & 40.3 & 41.0 & - & - & - & 30.1 & 31.2 & 32.0 \\
\hline Methyl eugenol & 0.60 & 0.50 & 0.46 & 0.16 & $\operatorname{tr}$ & $\operatorname{tr}$ & 0.52 & 0.30 & 0.40 & 1.60 & 1.30 & 1.30 \\
\hline (E)-Caryophyllene & 4.90 & 4.50 & 4.78 & 0.40 & 0.30 & 0.30 & 2.80 & 2.50 & 2.20 & 0.30 & 0.20 & $\operatorname{tr}$ \\
\hline $\begin{array}{l}\text { Trans- } \alpha- \\
\text { Bergamotene }\end{array}$ & 1.80 & 1.60 & 1.27 & 0.53 & 0.30 & 0.30 & 1.02 & 0.90 & 0.75 & 1.18 & 0.90 & 0.75 \\
\hline a-Guaiene & - & - & - & 0.23 & 0.25 & 0.15 & 0.26 & 0.20 & 0.10 & 0.37 & 0.30 & 0.30 \\
\hline a-Humulene & 1.90 & 1.80 & 1.67 & 0.53 & 0.30 & 0.10 & 0.42 & 0.30 & 0.25 & 0.23 & 0.10 & $\operatorname{tr}$ \\
\hline (E)- $\beta$-Farnesene & 0.50 & 0.40 & 0.42 & 0.33 & 0.30 & 0.20 & - & - & - & - & - & - \\
\hline Germacrene-D & 1.50 & 1.10 & 0.82 & 2.30 & 2.00 & 1.80 & 1.71 & 1.60 & 1.30 & 0.59 & 0.40 & 0.40 \\
\hline$\gamma$-Cadinene & 3.20 & 3.00 & 3.01 & 0.53 & 0.50 & 0.45 & 0.66 & 0.60 & 0.50 & 0.40 & 0.40 & 0.30 \\
\hline$\beta$-Bisabolene & 0.25 & 0.20 & 0.23 & - & - & - & - & - & - & - & - & - \\
\hline Nerolidol & 0.37 & 0.30 & 0.30 & 0.15 & 0.15 & 0.10 & - & - & - & 0.13 & 0.10 & 0.15 \\
\hline Caryophyllene oxide & 0.10 & 0.10 & 0.14 & 0.13 & $\operatorname{tr}$ & $\operatorname{tr}$ & - & - & - & - & - & - \\
\hline$\alpha$-Cadinol & - & - & - & 0.57 & 0.40 & 0.30 & - & - & - & 0.23 & 0.20 & 0.20 \\
\hline
\end{tabular}

N1: (control), N2: $100 \mathrm{~kg} \mathrm{ha}^{-1}$ urea , N3: $200 \mathrm{~kg} \mathrm{ha}^{-1}$ urea and tr: trace amounts $<0.05 \%$ 
essential oil extracted from the basil herb in the cultivar Italian Large Leaf seven constituents, i.e. 1,8-cineole (8.14 - $8.40 \%)$, linalool (41.9-44.8\%), methyl chavicol (30.7-37.0\%), eugenol (0.90-1.20 \%), (E)-caryophyllene (2.20-2.80\%), trans- $\alpha$-bergamotene (0.75-1.02\%) and germacrene-D (1.30-1.71\%) were the main constituents of essential oil (Table 3). Ten constituents including 1,8-cineole (1.45-1.60\%), (E)- $\beta$-ocimene (1.14-1.20\%), linalool (39.0-40.1\%), a-terpineol (0.80-1.10\%), methyl chavicol (9.30-11.3\%), eugenol (2.80-3.21\%), $\beta$-elemene (0.90-1.03\%), methyl cinnamate (30.1-32.0 \%), methyl eugenol (1.30-1.60\%) and trans- $\alpha$-bergamotene $(0.75-$ $1.18 \%$ ) were the main constituents of essential oil in the cultivar Thai (Table 3 ).

In order to monitor the change occurred in type and amount of essential oil's constituents, their contents in different treatments were carefully assayed. The highest amount of 1,8-cineole (8.40 \%) and linalool (44.8\%) were achieved by Italian Large Leaf cultivar and the application of 200 and $100 \mathrm{~kg} \mathrm{ha}^{-1}$ urea, respectively (Table 3). Nurzyńska-Wierdak et al. (2013) reported that linalool concentration increased after the application of the medium rate of nitrogen fertilizer and subsequently decreased after the highest rate was applied.

The highest amount of methyl chavicol (48.9\%) was achieved by Mobarakeh cultivar with the application of $200 \mathrm{~kg} \mathrm{ha}^{-1}$ urea; while the lowest (5.80\%) was obtained by Cinnamon cultivar without nitrogen fertilizer (Table 3). The availability of nitrogen in chemical fertilizer seemingly increased methyl chavicol concentration compared to other treatments. Zheljazkov et al. (2008) stated that nitrogen markedly changed the amount of linalool, eugenol, bornil-acetate and eucalyptol of essential oil of sweet basil. They continued that application of more nitrogen increased methyl chavicol while it decreased linalool of essential oil.

The highest content of Z-citral (neral) (17.0\%), geranial $(23.0 \%)$, (E)-caryophyllene (4.90\%), transa-bergamotene (1.80\%), a-humulene (1.90\%) and $\gamma$-cadinene $(3.20 \%)$ were observed by Mobarakeh cultivar without nitrogen fertilizer (Table 3). Some of detected constituents such as Z-citral (neral) and geranial were not observed in Cinnamon, Italian Large Leaf and Thai cultivars (Table 3). It appears that some factors like nutrient deficiency (especially nitrogen deficiency in the control treatment) could be considered as factors stimulating production of these constituents. Main constituents of essential oil are affected by diverse factors: water stress, salt stress and nutrition deficiencies resulting in alteration of essential oil constituents (Ekren et al., 2012; Barbieri et al., 2012). Based on Nurzyńska-Wierdak et al. (2013), different levels of nitrogen was shown to have a significant effect on the main constituents in the essen- tial oil of basil in such that the highest amount transa-bergamotene in sweet basil was found by lowest level of nitrogen. Kordi (2017) reported that among different sources of nitrogen, the highest amounts of Z-citral (neral), geranial, (E)-caryophyllene, trans- $\alpha$-bergamotene and $\alpha$-humulene were obtained by control (without nitrogen fertilizer).

One of the predominant components of the essential oil in Cinnamon and Thai cultivars was methyl cinnamate. The maximum amount of methyl cinnamate was achieved by Cinnamon cultivar and applying $200 \mathrm{~kg} \mathrm{ha}^{-1}$ urea, while the highest amount of germacrene-D was obtained by Cinnamon cultivar without nitrogen fertilizer (Table 3). In this regard, Kordi (2017) stated that the amount of germacrene-D decreased with increasing $\mathrm{N}$ supply. The highest content of eugenol (3.21\%) was observed by Thai cultivar without nitrogen fertilizer. In all cultivars, the trend of eugenol changes was similar to that of germacrene-D in fertilizer treatments and amount of this compound decreased with increasing nitrogen consumption (Table 3 ).

\section{CONCLUSIONS}

The results of the present study revealed that among different basil cultivars, Italian Large Leaf cultivar had the highest mean leaf dry mass, total dry mass, essential oil percentage and essential oil yield as compared to other cultivars. The lowest essential oil percentage and essential oil yield belonged to Mobarakeh cultivar. Application of urea fertilizer significantly improved vegetative growth, resulting in increased yield. Except essential oil percentage, all parameters evaluated in this study in the first harvest were lower than those at the other harvests. The highest yield of essential oil was attained by $100 \mathrm{~kg} \mathrm{ha}^{-1}$ urea fertilizer; although no-fertilizer treatment gave higher essential oil percentage than did nitrogen chemical fertilizer treatments, but $100 \mathrm{~kg} \mathrm{ha}^{-1}$ urea fertilizer treatment gave higher essential oil yield. This can be justified as essential oil yield was mainly affected by agricultural yield rather than essential oil percentage. The highest concentrations of main constituents of essential oil, except methyl chavicol, 1,8-cineole and methyl cinnamate were obtained by control (without nitrogen fertilizer); and this indicated an increase in content of the most main constituents of essential oil under treatment without nitrogen fertilizer, as compared to its nitrogen chemical fertilizers. Due to the fact that in terms of total dry yield there was no significant difference between application of 100 and $200 \mathrm{~kg} \mathrm{ha}^{-1}$ urea fertilizer and the highest yield of essential oil belonged to $100 \mathrm{~kg} \mathrm{ha}^{-1}$ urea fertilizer and also reduce the consumption of chemical 
fertilizers generating pollution, Italian Large Leaf cultivar and application of $100 \mathrm{~kg} \mathrm{ha}^{-1}$ urea are considered to access an acceptable agricultural yield and essential oil yield in sweet basil under environmental condition similar to Khorramabad.

\section{ACKNOWLEDGEMENTS}

This research was extracted from internal research project in Islamic Azad University, Khorramabad Branch. All material and spiritual rights of the paper are preserved for Islamic Azad University, Khorramabad Branch.

\section{REFERENCES}

Adams, R. P. (2007). Identification of essential oil components by gas chromatography/mass spectrometry. Allured Publishing Corporation, Carol Stream.

Al-Maskri, A. Y., Hanif, M. A., Al-Maskari, M. Y., Abraham, A. S., Al-Sabahi, J. N., Al-Mantheri, O. (2011). Essential oil from Ocimum basilicum (Omani Basil): a desert crop. Natural Product Communications, 6(10), 1487-1490. https://doi. org/10.1177/1934578X1100601020

Anonymous. (1996). European Pharmacopoeia. Council of Europe press, Strasbourg.

Barbieri, G., Vallone, S., Orsini, F., Paradiso, R., De Pascale, S., Negre-Zakharov, F., Maggio, A. (2012). Stomatal density and metabolic determinants mediate salt stress adaptation and water use efficiency in basil (Ocimum basilicum L.). Journal of Plant Physiology, 169, 1737-1746. https://doi. org/10.1016/j.jplph.2012.07.001

Beatović, D., Krstić-Milošević, D., Trifunović, S., Šiljegović, J., Glamočlija, J., Ristić, M., Jelačić, S. (2015). Chemical composition, antioxidant and antimicrobial activities of the essential oils of twelve Ocimum basilicum L. cultivars grown in Serbia. Records of Natural Products, 9, 62-75.

Biesiada, A., \& Kuś, A. (2010). The effect of nitrogen fertilization and irrigation on yielding and nutritional status of sweet basil (Ocimum basilicum L.). Acta Scientiarum Polonorum Hortorum Cultus, 9(2), 3-12.

Bilal, A., Jahan, N., Ahmed, A., Bilal, S. N., Habib, S., Hajra, S. (2012). Phytochemical and pharmacological studies on Ocimum basilicum Linn-a review. International Journal of Current Research and Review, 4(23), 73-83.

Borloveanu, M. (2014). Leacuri mănăstiresti. Terapii pentru trup si suflet. Lumea Credintei, Bucuresti.

Caliskan, S., Ozkaya, I., Caliskan, M. E., Arslan, M. (2008). The effects of nitrogen and iron fertilization on growth, yield and fertilizer use efficiency of soybean in Mediterraneantype soil. Field Crops Research, 108(2), 126-132. https://doi. org/10.1016/j.fcr.2008.04.005

Carneiro, N. S., Alves, C. C. F., Alves, J. M., Egea, M. B., Martins, C. H. G., Silva, T. S., Bretanha, L. C., Balleste, M. P., Micke, G. A., Silveira, E. V., Miranda, M. L. D. (2017). Chemical composition, antioxidant and antibacterial activities of essential oils from leaves and flowers of Eugenia klotzchiana Berg (Myrtaceae). Anais da Academia Brasileira de Ciências, 89(3), 1907-1915. https://doi.org/10.1590/00013765201720160652

Ekren, S., Sönmez, C., Özcakal, E., Kurttas, Y. S. K., Bayram, E., Gürgülü, H. (2012). The effect of different irrigation water levels on yield and quality characteristics of purple basil (Ocimum basilicum L.). Agricultural Water Management, 109, 155-161. https://doi.org/10.1016/j.agwat.2012.03.004

Jahan, M., Amiri, M. B., Tahami, M. K., Bajouri, S. (2012). The effect of biofertilizers and winter cover crops on essential oil production and some agroecological characteristics of basil (Ocimum basilicum $\mathrm{L}$ ) in an organic cropping system. In $13^{\text {th }}$ Congress of the International Society for Ethnopharmacology.

Kandil, M. A. M., Khatab, M. E., Ahmed, S. S., Schnug, E. (2009). Herbal and essential oil yield of Genovese basil (Ocimum basilicum L.) grown with mineral and organic fertilizer sources in Egypt. Journal für Kulturpflanzen, 61(12), 443-449.

Kordi, S. (2017). Evaluation of quantitative and qualitative characteristics of forage corn (Zea mays L.) and sweet basil (Ocimum basilicum L.) under nitrogen fertilizers (biological, chemical and integrated) in additive intercropping. Ph.D. Thesis, Faculty of Agriculture, University of Tabriz, Tabriz, Iran.

Krishnaiah, D., Devi, T., Bono, A., Sarbatly, R. (2009). Studies on phytochemical constituents of six Malaysian medicinal plants. Journal of Medicinal Plants Research, 3(2), 67-72.

Lawlor, D. W. (2002). Carbon and nitrogen assimilation in relation to yield: mechanisms are the key to understanding production systems. Journal of experimental Botany, 53, 773-787. https://doi.org/10.1093/jexbot/53.370.773

Li, H., Ge, Y., Luo, Z., Zhou, Y., Zhang, X., Zhang, J., Fu, Q. (2017). Evaluation of the chemical composition, antioxidant and antiinflammatory activities of distillate and residue fractions of sweet basil essential oil. Journal of Food Science and Technology, 54(7), 1882-1890. https://doi. org/10.1007/s13197-017-2620-x

Nurzyńska-Wierdak, R., Borowski, B., Dzida, K., Zawiślak, G., Kowalski, R. (2013). Essential oil composition of sweet basil cultivars as affected by nitrogen and potassium fertilization. Turkish Journal of Agriculture and Forestry, 37, 427-436. https://doi.org/10.3906/tar-1203-43

Padalia, R. C., Verma, R. S., Chauhan, A., Goswami, P., Chanotiya, C. S., Saroj, A., Samad, A., Khaliq, A. (2014). Compositional variability and antifungal potentials of Ocimum basilicum, O. tenuiflorum, O. gratissimum and O. kilimandscharicum essential oils against Rhizoctonia solani and Choanephora cucurbitarum. Natural Product Communications, 9(10), 1507-1510. https://doi. org/10.1177/1934578X1400901026

Ram, M., Ram, D., Prasad, A., Naqvi, A., Kumar, S. (1998). Productivity of late transplanted mint (Mentha arvensis) with summer legume inter crops in a sub-tropical environment. Journal of Medicinal and Aromatic Plant Sciences, 20, 1028 1031. 
Roman, G.V. (2012). Fitotehnie. Plante Tehnice, Medicinale si Aromatice. Editura Universitară, Bucuresti.

Sifola, M. I., \& Barbieri, G. (2006). Growth, yield and essential oil content of three cultivars of basil grown under different levels of nitrogen in the field. Scientia Horticulturae, 108(4), 408-413. https://doi.org/10.1016/j.scienta.2006.02.002

Simon, J. E., Morales, M. R., Phippen, W. B., Vieira, R. F., Hao, Z. (1999). Basil: a source of aroma compounds and a popular culinary and ornamental herb. Perspectives on New Crops and New Uses, 499-505.

Srivastava, S., Cahill, D. M., Conlan, X.A., Adholeya, A. (2014). A novel in vitro whole plant system for analysis of polyphenolics and their antioxidant potential in cultivars of Ocimum basilicum. Journal of Agricultural and Food Chemistry, 62(41), 10064-10075. https://doi.org/10.1021/jf502709e

Street, R. (2012). Heavy metals in medicinal plant products-An African perspective. South African Journal of Botany, 82, 67-74. https://doi.org/10.1016/j.sajb.2012.07.013
Tahami Zarandi, M. K., Rezvani Moghaddam, P., Jahan, M. (2010). Comparison the effect of organic and chemical fertilizers on yield and essential oil percentage of basil (Ocimum basilicum L.). Journal of Agroecology, 2(1), 70-82.

Werner, D., \& Newton, W. E. (2005). Nitrogen fixation in agriculture, forestry, ecology and environment. Springer, Netherlands. https://doi.org/10.1007/1-4020-3544-6

Yassen, M., Ram, P., Anju, Y., Singh, K. (2003). Response of Indian basil (Ocimum basilicum) to irrigation and nitrogen schedule in Central Uttar Pradesh. Annals of Plant Physiology, 17(2), 177-181.

Zheljazkov, V. I., Cantrell, C. L., Ebelhar, M. W., Rowe, D. E., Coker, C. (2008). Productivity, oil content and oil composition of sweet basil as a function of nitrogen and sulphur fertilization. HortScience, 43(5), 1415-1422. https://doi. org/10.21273/HORTSCI.43.5.1415 